\author{
Prof. dr. sc. Duško Lozina, redoviti profesor u trajnom zvanju ${ }^{1}$ \\ Pravni fakultet Sveučilišta u Splitu \\ Dr. sc. Damir Juras ${ }^{2}$ \\ MUP Split
}

\title{
TEORIJSKI PRISTUPI O PODRUČNOJ (REGIONALNOJ) SAMOUPRAVI U REPUBLICI HRVATSKOJ
}

\author{
UDK: 352 (497.5) \\ Primljeno: 10. 02. 2019. \\ Izvorni znanstveni rad
}

Hrvatska se kao samostalna država, a od 2013. godine i punopravna članica Europske unije, odredila za punu afirmaciju institucija lokalne i područne (regionalne) samouprave. Hrvatska upravna znanost napravila je značajne iskorake u smislu prihvaćanja temeljnih zasada europskog profiliranja tih institucija, ali svjesna i svojih posebnosti na tom putu. Kao jedna od najvažnijih dvojbi javlja se ona o koncepciji područne (regionalne) samouprave odnosno o tome kako organizirati to područje, posebice koji teritorij bi obuhvaćale jedinice područne (regionalne) samouprave i prema kojim kriterijima bi taj teritorij bio određen te koje ovlasti bi takve jedinice imale. Radi cjelovite kritičke analize ključnih pitanja područne (regionalne) samouprave u Republici Hrvatskoj, u radu se analiziraju stajališta znanstvenika i iz drugih područja: ekonomista, politologa, geografa i sociologa.

Ključne riječi: područna (regionalna) samouprava, regije, regionalizam, Republika Hrvatska, teritorijalni ustroj, županija

\section{UVOD}

Pravo na područnu samoupravu u Republici Hrvatskoj zajamčeno je čl. 128.131. Ustava Republike Hrvatske, ${ }^{3}$ koji propisuje da su županije jedinice područne (regionalne) samouprave, čije područje se određuje na način propisan zakonom, a zakonom se može glavnom gradu Zagrebu utvrditi položaj županije. Jedinice lokalne samouprave su gradovi i općine. Jedinice područne (regionalne) samouprave obavljaju poslove od područnog (regionalnog) značenja, a osobito poslove koji se odnose na školstvo, zdravstvo, prostorno i urbanističko planiranje, gospodarski razvoj, promet i prometnu infrastrukturu te planiranje i razvoj mreže obrazovnih, zdravstvenih, socijalnih i kulturnih ustanova. Poslovi lokalnog i područnog

1 Pravni fakultet u Splitu, redoviti profesor u trajnom zvanju, e.-mail: duskolozina7@gmail.com

${ }^{2}$ Voditelj Odjela prvostupanjskog disciplinskog sudovanja Ministarstva unutarnjih poslova u Splitu, glavni policijski savjetnik, e-mail: Damir.Juras@alnet.hr, djuras@mup.hr. Autor u tekstu iznosi osobna stajališta.

${ }^{3}$ Ustav Republike Hrvatske, NN 56/90, 135/97, 113/00, 28/01, 76/10, 5/14. Č. 4. st. 1. Ustava propisano je da je državna vlast, koja je ustrojena na načelu diobe vlasti na zakonodavnu, izvršnu i sudbenu, ograničena Ustavom zajamčenim pravom na lokalnu i područnu (regionalnu) samoupravu. 
Dr. sc. Duško Lozina i Dr. sc. Damir Juras: Teorijski pristupi o područnoj (regionalnoj) samoupravi u... Zbornik radova Pravnog fakulteta u Splitu, god. 56, 2/2019., str. 423.- 442.

(regionalnog) djelokruga uređuju se zakonom. Prilikom dodjeljivanja tih poslova prednost će imati ona tijela koja su najbliža građanima, a pri određivanju djelokruga jedinica lokalne i područne (regionalne) samouprave mora se voditi računa o širini i prirodi poslova i o zahtjevima učinkovitosti i ekonomičnosti. U obavljanju poslova iz svojeg djelokruga tijela jedinica lokalne i područne (regionalne) samouprave samostalna su i podliježu samo nadzoru ustavnosti i zakonitosti ovlaštenih državnih tijela. Jedinice lokalne i područne (regionalne) samouprave imaju pravo na vlastite prihode kojima slobodno raspolažu u obavljanju poslova iz svojeg djelokruga. Prihodi jedinica lokalne i područne (regionalne) samouprave moraju biti razmjerni njihovim ovlastima predviđenima Ustavom i zakonom.

Uspostava sadašnjeg sustava lokalne i područne samouprave u Republici Hrvatskoj započela je 1992. donošenjem Zakona o lokalnoj samoupravi i upravi ${ }^{4}$ i Zakona o područjima županija, gradova i općina. ${ }^{5}$ Pravne odredbe o poslovima i područjima jedinica područne samouprave u Republici Hrvatskoj sada su sadržane u Zakonu o lokalnoj i područnoj (regionalnoj) samoupravi ${ }^{6}$ i Zakonu o područjima županija, gradova i općina u Republici Hrvatskoj. ${ }^{7}$ U ovom trenutku u Republici Hrvatskoj ustrojeno je 428 općina, 127 gradova, 20 županija odnosno jedinica područne samouprave, a grad Zagreb, kao glavni grad Republike Hrvatske, ima poseban status grada i županije, ${ }^{8}$ pa u Republici Hrvatskoj sveukupno ima 576 jedinica lokalne i područne samouprave. ${ }^{9}$

Zakonom o lokalnoj i područnoj (regionalnoj) samoupravi (čl. 6., 14., 16., 20., 22. i 23.) propisano je: da županija predstavlja jedinicu područne (regionalne) samouprave čije područje predstavlja prirodnu, povijesnu, prometnu, gospodarsku, društvenu i samoupravnu cjelinu, a ustrojava se radi obavljanja poslova od područnog (regionalnog) interesa; da županije mogu surađivati s odgovarajućim jedinicama lokalne i regionalne samouprave drugih država, a nadzor nad zakonitošću odluke županije o navedenoj suradnji obavlja središnje tijelo državne uprave nadležno za lokalnu i područnu (regionalnu) samoupravu; da županija u svom samoupravnom djelokrugu obavlja poslove od područnoga (regionalnog) značaja, a osobito poslove koji se odnose na: obrazovanje, zdravstvo, prostorno i urbanističko planiranje,

${ }^{4}$ Zakon o lokalnoj samoupravi i upravi, NN 90/92, 94/93, 117/93, 5/97, 17/99, 128/99, 51/00, 105/00.

5 Zakon o područjima županija, gradova i općina u Republici Hrvatskoj, NN 90/92, 2/93, 58/93, 90/93, 10/94, 29/94.

6 Zakon o lokalnoj i područnoj (regionalnoj) samoupravi, NN 33/01, 60/01, 129/05, 109/07, 125/08, 36/09, 150/11, 144/12, 19/13, 137/15, 123/17.

7 Zakon o područjima županija, gradova i općina u Republici Hrvatskoj, NN 86/06, 125/06, 16/07, 95/08, 46/10, 145/10, 37/13, 44/13, 45/13, 110/15

8 Čl. 2. Zakona o Gradu Zagrebu, NN 62/01, 125/08, 36/09, 119/14.

9 Prema podacima Državne geodetske uprave, na dan 31. III. 2011., računajući samo površinu kopna, https://www.dzs.hr/hrv/censuses/census2011/results/xls/Preg_01_HR.xls (uvid 13. XII. 2018.), po površini su najveće Ličko-senjska $\left(5353 \mathrm{~km}^{2}\right)$ i Splitsko-dalmatinska $\left(45 \overline{4} 0 \mathrm{~km}^{2}\right)$, a najmanje Grad Zagreb $\left(641 \mathrm{~km}^{2}\right)$ i Međimurska županija $\left(729 \mathrm{~km}^{2}\right)$; najviše stanovnika imaju Grad Zagreb (790.017) i Splitskodalmatinska županija (454.798), a najmanje stanovnika prebiva u Ličko-senjskoj (50.927) i Požeškoslavonskoj (78.034), dok na području županije najmanje naselja imaju Grad Zagreb (70) i Vukovarskosrijemska županija (85), a najviše Zagrebačka (694) i Splitsko-dalmatinska županija (655). 
gospodarski razvoj, promet i prometnu infrastrukturu, održavanje javnih cesta, planiranje i razvoj mreže obrazovnih, zdravstvenih, socijalnih i kulturnih ustanova, izdavanje građevinskih i lokacijskih dozvola, drugih akata vezanih uz gradnju te provedbu dokumenata prostornog uređenja za područje županije izvan područja velikog grada, ${ }^{10}$ te ostale poslove sukladno posebnim propisima, da se odlukom predstavničkog tijela jedinice lokalne samouprave, u skladu s njezinim statutom i statutom županije, pojedini poslovi iz samoupravnog djelokruga jedinice lokalne samouprave mogu prenijeti na županiju odnosno mjesnu samoupravu; da se poslovi državne uprave koji se obavljaju u jedinici lokalne samouprave i u jedinici područne (regionalne) samouprave određuju zakonom.

Kad je riječ o hrvatskoj područnoj (regionalnoj) samoupravi potrebno je poći od stava da je ona od vremena normativne uspostave 1992. godine prošla kroz izrazito turbulentno razdoblje. Doduše, i druge su europske države prošle kroz različite faze organiziranja lokalne i regionalne samouprave pa je svrhovito govoriti o različitim tradicijama i modelima. ${ }^{11}$ Naravno da treba poštovati činjenice postojanja nacionalnih posebnosti, ali iz hrvatske perspektive treba voditi računa i o temeljnoj tendenciji da se uspostavi europski upravni prostor, što znači da se i sfera područne (regionalne) samouprave sve više unificira.

Predmet ovog rada je analiza teorijskih stajališta (primjedbi i prijedloga) određenih hrvatskih stručnjaka iz različitih znanstvenih područja, iznesena u razdoblju stvaranja i opstojnosti županija kao jedinica lokalne uprave i samouprave odnosno područne (regionalne) samouprave, o modelima regionalne (područne) samouprave u Republici Hrvatskoj, posebice u pogledu teritorija i ovlasti postojećih odnosno budućih jedinica područne (regionalne) samouprave. Kritički pristup navedenim stajalištima sadrži i prijedlog rješenja uočenih manjkavosti i problema.

\section{STAJALIŠTA STRUČNJAKA IZ PODRUČJA UPRAVNE ZNANOSTI}

Iako je znanost otvoreni i prije svega interdisciplinarni pristup, posebnu važnost imaju stajališta stručnjaka iz područja upravne znanosti.

10 Veliki gradovi su jedinice lokalne samouprave koje su ujedno gospodarska, financijska, kulturna, zdravstvena, prometna i znanstvena središta razvitka šireg okruženja i koje imaju više od 35.000 stanovnika (čl. 19. a Zakona o lokalnoj i područnoj (regionalnoj) samoupravi).

11 Poznato je da je medievalni europski prostor bio izrazito partikularan, obilježen visokim stupnjem fragmentacije, sve do uspostave ideje nacionalne države koja se u recentnom razdoblju kritizira kao zapreka bitnim odrednicama globalnih kretanja koja promiču ideju mobilnosti ljudi, rada i kapitala. Ideja regionalizacije javlja se, povijesno gledano, kao reakcija na ideje francuske buržoaske revolucije iz 1789. godine. U suvremenom razdoblju ,kao razlozi jačanja regionalizma na razvijenom europskom zapadu navode se procesi demokratizacije pojedinih zemalja (Spanjolska), olakšavanje upravljanja centralističkim državama (Francuska), očuvanje jedinstva zemlje (Belgija), ali i zaštita i jačanje regionalnih identiteta pred naletom unificirajuće nadnacionalne Europske unije“" - Koprić, I., „Uloga županija u hrvatskom sustavu lokalne samouprave i uprave 1990-ih i perspektive regionalizacije nakon promjena Ustava iz 2000. godine“, Hrvatska javna uprava, Zagreb, god. 3, 2001., broj 1., str. 64. 
Unutar upravnog diskursa posebno je suptilno o ovoj tematici pisao Đulabić koji daje definicije ključnih pojmova bitnih za razumijevanje i rješavanje problematike područne (regionalne) politike. On regiju definira kao ,područje koje ima specifične karakteristike koje omogućuju da ga se percipira kao zasebnu i koherentnu cjelinu te na kojem postoje političke odnosno upravne institucije različite od takvih institucija na lokalnoj, tj. nacionalnoj razini“, ${ }^{12}$ regionalizam označava kao „svojevrsno ideološko usmjerenje kojega je temeljna nit vodilja jačanje regionalne razine vlasti koja je izvjesna protuteža središnjoj vlasti. Regionalizam je proces koji je uvijek iniciran odozdo (bottom-up) i izraz je nastojanja da regionalne jedinice imaju što je moguće veću kontrolu nad cjelokupnim društvenim, ekonomskim, političkim i drugim procesima na svom području“ ${ }^{13}$ regionalnu samoupravu definira kao „pravni izričaj“14 regionalizma, regionalizaciju označava kao „proces uspostave regija koji je iniciran s nacionalne, državne razine“ s ciljem da se uvede „regionalni sustav upravljanja s manjim ili većim stupnjem autonomije“, ${ }^{15}$ a regionalnu politiku Europske unije definira kao „posebnu vrst ekonomske politike usmjerene prema povećanju konkurentnosti gospodarstva onih područja koja zaostaju za europskim prosjekom. " ${ }^{16}$ Ističući bit regionalizma kao nastojanja da regionalne jedinice, a time i njihovo stanovništvo, zadobije veću kontrolu nad procesima koji su ključni za njihov opstanak i razvoj, ovaj autor ukazuje da je težnja za regionalizmom suprotnost separatističkim težnjama koje, kod građana koji ne poznaju odnosno kojima nisu prezentirane bitne odrednice i prednosti regionalizma, izazivaju otpor prema stvaranju i jačanju političkih regija. Ističući da je osnivanjem Europskog fonda za regionalni razvoj (ERDF) 1975. godine, ,naglašena regionalna dimenzija razvojne politike EU i tim potezom učinjen bitan doprinos jačanju ideje o regionalnoj razini upravljanja javnim poslovima“", ${ }^{17}$ Đulabić kroz regionalnu politiku Europske unije ističe i ekonomske blagodati regionalnog organiziranja. Klasificirajući regionalne jedinice na ,i) upravne, administrativne, ii) planske, razvojne, iii) političke, iv) statističke, v) kulturne, etničke, povijesne, vi) ekonomske i vii) funkcionalne"18 i precizirajući da su upravne odnosno administrativne regije ,izraz državne politike i pristupa izgradnji države „odozgo“ (top-down pristup)“, ${ }^{19}$ Đulabić ističe administrativne regije kao sredstvo centralizacije državne vlasti nasuprot političkim (samoupravnim) regijama, kao oblicima političke regionalne (područne) samouprave, kojima se ograničava i decentralizira državna vlast. Ovaj autor pravi i jasnu razliku u svrsi političke i statističke ${ }^{20}$ regionalizacije, naglašavajući da se

12 Đulabić, V., Regionalizam i regionalna politika, Društveno veleučilište, Zagreb, 2007., str. 72.

13 Đulabić, V., op. cit., str. 75.

14 Đulabić, V., op. cit., str. 76

15 Đulabić, V., op. cit., str. 78.

16 Đulabić, V., op. cit., str. 99

17 Đulabić, V., op. cit., str. 53.

18 Đulabić, V., op. cit., str. 55

19 Đulabić, V., op. cit., str. 56.

20 Statistička regionalizacija odnosno statističke regije služe prikupljanju podataka za vođenje regionalne politike Europske unije. Najznačajnija statistička klasifikacija teritorija je tzv. NUTS 
one ne moraju podudarati odnosno da ih je potrebno „odvojeno tretirati ako se žele postići praktične koristi od svakog od navedenih tipova regionalizacije.“21

Uvažavajući složenost organizacije i rada te značaj uprave za razvoj društva i njegovih građana, Lalić ukazuje na nužnost primjene komparativne metode u proučavanju uprave, pri čemu ističe da u komparativnom pristupu posebice valja naglasiti značaj nekoliko teorijskih pristupa od kojih su najvažniji ,neoinstitucionalni, ekološki, strukturno-funkcionalistički i birokratski pristup." ${ }^{22}$

Polazeći od rezultata istraživanja provedenog na području Dalmacije na uzorku od 3000 ispitanika, prema kojem ,više od $45 \%$ ispitanika ocjenjuje dosadašnju teritorijalnu diobu na županije „lošom“ i ,izuzetno lošom“. Usto, preko $45 \%$ ispitanika izjašnjava se u prilog smanjenju broja županija, odnosno njihovu svođenju na šest povijesnih regija" ${ }^{23}$ Cvitan ukazuje na važnost uvažavanja percepcije i mišljenja građana o granicama teritorijalnih jedinica.

Analizirajući Nacrt Europske povelje o regionalnoj samoupravi iz 1997. Babac naglašava „da 'pripoznavanje regionalne samouprave' imade za nužnu posljedicu 'odanost i privrženost državi kojoj regije pripadaju' te stvaranje 'uravnoteženog razvitka'“24 i postavlja „Zahtjev za obnovom i modernizacijom „historičkoga županijskog ustroja“" u Hrvata što, ukratko i načelno, znači: a) uspostavljanje županija kao 'regija', kao samoupravnih korporacija javnoga prava na regionalnoj razini, što će reći županije kao jedinstva 'srednjega stupnja uprave', 'političke zajednice na regionalnoj razini' te 'zajednice lokalnih oblasti svojega ozemlja' (općine te gradovi i kotari); b) ustrojavanje lokalnih, regionalnih i središnjih oblasti, uz priuzdržaj zasebnoga režima za naravni djelokrug, s pomoću jedinstvene javne funkcije, posebice i temeljnoga upravnog stupnja u obliku kotara; c) priznavanje široke lokalne i regionalne samouprave kroz općine i gradove te županije, uz njihovu relativno visoku financialnu samostalnost, sve to unutar odredbenica 'nacionalne razvojne politike' i objedinjavanja njihovoga djelovanja kroz 'regiju', dotično kroz 'županiju ustrojenu kao regija'.'“25

klasifikacija koju je utemeljio EUROSTAT i ona obuhvaća tri kategorije teritorijalnih jedinica ovisno o broju stanovnika, pa tako razina NUTS 1 obuhvaća područje od 3 do 7 milijuna stanovnika, razina NUTS 2 područje od 800.000 do 3 milijuna stanovnika, a razina NUTS 3 područje od 150.000 do 800.000 stanovnika. Klasifikacijski sustav NUTS uređen je Uredbom (EZ) 1059/2003 od 26. V. 2003. o uspostavi zajedničke klasifikacije teritorijalnih jedinica za statistiku.

${ }_{21}$ Đulabić, V., „Položaj županija u statističkoj i političkoj regionalizaciji Hrvatske“, Dvadeset godina lokalne samouprave u Hrvatskoj (ur. I. Koprić), Institut za javnu upravu, Zagreb, 2013., str. 183.

22 Lalić-Novak, G., „Komparativna metoda u proučavanju javne uprave: potencijali i problemi“, Hrvatska i komparativna javna uprava, god. 15, 2015., broj 1, str. 25.

23 Cvitan, O., Uvodnik znanstveno-stručnog skupa: Teritorijalni ustroj i regionalizacija Republike Hrvatske u kontekstu Europskih integracija, Teritorijalni ustroj i regionalizacija Republike Hrvatske $u$ kontekstu Europskih integracija: zbornik radova, ur. Cvitan, O., Split, 2010., str. 14.

24 Babac, B., „Oblikovanje hrvatskoga regionalnog političko-upravnog ustrojstva u razmeđu suvremenosti, nacionalne tradicije i europeizacije - prethodni iskazi“, Teritorijalni ustroj i regionalizacija Republike Hrvatske u kontekstu Europskih integracija: zbornik radova, ur. Cvitan O, Split, 2010., str. 55.

${ }_{25}$ Babac, B., op. cit., str. 69. 
Naglašavajući državotvornu ulogu županija tijekom povijesti, ali ukazujući i na značaj ovlasti kojima raspolažu, Lozina ističe da su ,do revolucionarne 1848. godine županije predstavljale najtvrđi bedem narodne samostalnosti, tim više jer su one činile izvršnu vlast koja je unutar svojih granica izvršavala saborske zaključke u upravnom, poreznom i vojničkom pogledu. ${ }^{26}$

Autorica Grubišin navodi da hrvatske regije predstavljaju grupu povijesnih, često preklapajućih regija: Banija (ili Banovina), Baranja, Dalmacija, Gorski kotar, Istra, Hrvatsko primorje, Kordun, Lika, Međimurje, Podravina, Podunavlje, Posavina, Prigorje, Slavonija, Srijem, Zagorje (ili Hrvatsko zagorje). ${ }^{27}$

Upozoravajući na potrebu sprečavanja centralizacije u središtu novih regija, Blažević predlaže stvaranje ,,četiri prirodne regije. To bi bile Slavonija (oko 891.000 stanovnika), Središnja Hrvatska (oko 1.241.000 stanovnika), Riječka regija s Istrom, Gorskim kotarom i dijelom Ličko-senjske županije (Otočac, Senj, dio otoka Paga) te Karlovačkom županijom (oko 700.000 stanovnika) i Dalmacija (oko 900.000 stanovnika). Četiri najveća hrvatska grada bila bi središta novih regija. Pritom valja voditi računa o odgovarajućoj disperziji ovlasti između središta regija i periferije. “"

Unutar upravnog diskursa o ovoj problematici svakako je autoritativno Koprićevo stajalište. Respektirajući značaj i ukupne kapacitete srednjih i većih gradova, on uočava da „općine nisu u stanju obavljati ustavni krug dodijeljenih im javnih poslova, čak ni u nekom smanjenom opsegu, jer nemaju financijskih, ljudskih ni organizacijskih kapaciteta za takvu vrstu zadaća“ ${ }^{29}$ dok ,„̌̌upanije funkcioniraju kao lokalne, a ne regionalne jedinice“ ${ }^{30}$ pa predlaže formiranje vlasti koju bi „,sačinjavalo dvadesetak županija i osamdesetak većih i srednjih gradova na lokalnoj razini te pet novih, samoupravnih regija“, ${ }^{31}$ a te ,političke regije valjalo bi koristiti kao okvir za planiranje, razvojno povezivanje te međužupanijsko usklađivanje javnih politika." ${ }^{\text {"32 }}$ Koprić predlaže da se ustroji 5 regija ,s tim da nijedna ne bi smjela imati manje od 800.000 stanovnika. One bi se formirale na povijesnom i funkcionalnom, a ne pukom administrativnom kriteriju. Nove bi regije ujedno služile kao jedinice NUTS II, a formirale bi se uglavnom po granicama postojećih županija, tako da obuhvate neki broj njih. (...) Prema Popisu stanovništva iz 2001. godine, uz granice regija određene granicama postojećih županija te bi regije obuhvaćale sljedeće:

26 Lozina, D., Lokalna samouprava - poredbeno i hrvatsko iskustvo, Pravni fakultet u Splitu, Split, 2004., str. 52.

27 Vidi detaljnije u: Grubišin, M., „O mjerilima i kriterijima teritorijalnog ustroja Republike Hrvatske u odnosu na države njenog okruženja“", Teritorijalni ustroj i regionalizacija Republike Hrvatske u kontekstu Europskih integracija: zbornik radova, ur. Cvitan O, Split, 2010., str. 173-174.

28 Blažević, R., „Hrvatske regije i županije u povijesnom ključu“, Nova hrvatska lokalna i regionalna samouprava (ur. J. Barbić), Zagreb, HAZU, 2010., str. 194.

29 Koprić, I., „Je li moguća regionalizacija Hrvatske? Institucionalna i politička ograničenja“, Političke analize, god. 5, 2014., broj 17, str. 11.

30 Koprić, I., op. cit., str. 12.

31 Koprić, I., op. cit., str. 13.

32 Koprić, I., op. cit., str. 13. 
- Središnja Hrvatska sa sjedištem u Varaždinu trebala bi obuhvatiti neke postojeće županije, i to Međimursku, Varaždinsku, Krapinsko-zagorsku, Koprivničko-križevačku te Bjelovarsko-bilogorsku (sada tih pet županija ima 703.178 stanovnika), a vjerojatno i istočni dio Zagrebačke županije, pa čak možda i područje oko Siska,

- Slavonija sa sjedištem u Osijeku trebala bi obuhvatiti Osječko-baranjsku, Vukovarsko-srijemsku, Virovitičko-podravsku, Požeško-slavonsku i Brodskoposavsku županiju (sada s ukupno 891.259 stanovnika), a vjerojatno i istočni dio Sisačko-moslavačke županije,

- Primorje i Istra sa sjedištem u Rijeci trebala bi obuhvatiti Istarsku, Primorskogoransku, Karlovačku i Ličko-senjsku županiju (sada s ukupno 707.313 stanovnika), a vjerojatno i zapadni dio Sisačko-moslavačke županije,

- Dalmacija sa sjedištem u Splitu obuhvaćala bi postojeće županije, i to Zadarsku, Šibensko-kninsku, Splitsko-dalmatinsku i Dubrovačko-neretvansku (sada s ukupno 861.482 stanovnika),

- Zagrebačka regija, koja bi obuhvaćala Grad Zagreb te dijelove Zagrebačke županije, a u svakom slučaju područje postojećih gradova Samobor, Zaprešić, Velika Gorica i Dugo Selo.“"33

Ukazujući na načelo supsidijarnosti kao temelj određivanja i širenja djelokruga poslova regija, Klarić u svom tekstu ističe da je regionalizam u Europi, kao ideja, „zastupljen u više dokumenata. Iako ti dokumenti nemaju obvezujući karakter, značajni su jer ukazuju na ulogu regionalizma i regionalizacije u Europi. Tako je Europski parlament 1988. godine usvojio Povelju Zajednice o regionalizaciji (Community Chapter for Regionalization) kojom se željelo potaknuti države članice na harmonizaciju njihovih unutarnjih uređenja s obzirom na regionalnu razinu. Drugi značajni dokument je Deklaracija o regionalizmu u Europi (Declaration on regionalismin Europe), koji je usvojen u okviru Skupštine europskih regija. Treći dokument je Nacrt Europske povelje o regionalnoj samoupravi (Draft European Chapter of Regional Self-Government) koji promiče ideju regija kao najvećih teritorijalnih jedinica u državi te načelo supsidijarnosti kao instrument oblikovanja njihovog samoupravnog djelovanja." ${ }^{\text {"34 }}$

Ivaniševićje ustvrdio da za obavljanje poslova iz djelokruga područne (regionalne) samouprave, izuzev poslova državne uprave, ,područje sadašnjih županija u većini slučajeva nije pogodan teritorijalni okvir već bi taj okvir trebalo prilagoditi regionalnoj strukturi Hrvatske. U Hrvatskoj postoji pet prirodnih i povijesnih regija (Primorje, Dalmacija, gorska Hrvatska, sjeverna Hrvatska i Slavonija) te nekoliko izdvojenih subregija s posebnim identitetom (Istra, dubrovački kraj, Međimurje,

33 Koprić, I., „Teritorijalna organizacija Hrvatske: stanje, kriteriji za prosudbu racionalnosti i prijedlog novog sustava“, Nova hrvatska lokalna i regionalna samouprava (ur. J. Barbić), Zagreb, HAZU, 2010., str. 135 .

34 Klarić, M., „Moguće perspektive razvoja lokalne i regionalne samouprave u Republici Hrvatskoj“", u: Teritorijalni ustroj i regionalizacija Republike Hrvatske u kontekstu Europskih integracija: zbornik radova, ur. Cvitan O, Split, 2010., str. 103. 
Baranja, istočna Slavonija i zapadni Srijem). Na toj bi strukturi trebalo izgraditi regionalnu organizaciju Hrvatske, što bi se moglo postići povezivanjem županija sa sličnim razvojnim interesima. Postojeće županije mogle bi ostati kao upravne jedinice preko kojih bi bilo organizirano obavljanje poslova državne uprave na terenu." ${ }^{35}$

\section{STAJALIŠTA EKONOMISTA}

Švaljek ispravno označava bit regionalizma koji se sastoji u optimalnom korištenju ukupnih resursa regije radi ekonomskog prosperiteta regije i njezinih stanovnika, a nasuprot političkim projektima koji žele stvoriti ili ojačati regije u smislu stvaranja autonomnih političkih subjekata, pa na primjeru Istre navodi da bi ,regije pa tako i Istra, morale ponovno razvijati svoj identitet - i politički i gospodarski i kulturni - pridonoseći tako rastu nacionalne države. U takvom su međusobnom odnosu isključene prenaglašene centralističke tendencije, ali i one neoregionalističke tendencije kojima bi svrha bila promoviranje pritajenih i besmislenih regionalističkih težnji. “36 Ona smatra da bi se regije ,morale pomiriti sa činjenicom da cilj regije nije političko već gospodarsko jačanje, a to podrazumijeva da se uspješnost neke regije pokazuje u procesu tržišnog vrednovanja."“37

Prihvaćajući stajalište da regionalizam u Hrvatskoj ima svoje prirodno i povijesno podrijetlo, Šimunović navodi da je jedna ,od najstarijih regionalnih podjela Hrvatske ona po kojoj se Hrvatska dijeli na panonsku, planinsku i priobalnu Hrvatsku. “38 Šimunović smatra da, bez obzira na brojne diobe regija, ovisno o disciplini koja ih proučava, središnje značenje pripada funkcionalnim regijama. U takvim regijama „grad-središte postaje nositelj društvenog i gospodarskog napretka i žarište svih socijalnih i kulturnih događanja u gravitacijskom području tih središta. “39 $\mathrm{Na}$ ovaj način Šimunović upućuje na potrebu da se Republika Hrvatska regionalno podijeli, uz uvažavanje svih ostalih kriterija (koji su već propisani Zakonom) na regije u čijem središtu bi bili najveći gradovi. ${ }^{40}$ Šimunović je devedesetih godina prošlog stoljeća, dakle u vrijeme povratka koncepta lokalne samouprave u politički i upravni poredak RH, ustvrdio da „,najveća pogreška u regionalnoj povijesti Hrvatske jest u

35 Ivanišević, S., ,Teritorijalna osnova lokalne i regionalne samouprave uz posebni osvrt na položaj grada Zagreba i njegovu samoupravu“, Hrvatska javna uprava, god. 2, 2000., broj 4, str. 590-591.

36 Švaljek, S., ,Regionalni identitet Istre“, Ekonomski pregled, god. 46, 1995., broj 3-4, str. 254.

37 Švaljek, S., op. cit., str. 257. str. 299.

38 Šimunović, I., „Hrvatski i europski regionalizam“, Ekonomski pregled, god. 46, 1995., broj 3-4,

39 Šimunović, I., Planiranje ili pravo na budućnost, Marjan tisak, Split, 2005., str. 189.

40 Prema Popisu stanovništva iz 2011. godine,

file://C:/Users/djuras/Documents/Državni\%20zavod\%20za\%20statistiku\%20Republike\%20 Hrvatske.pdf(uvid 17. XII. 2018.), najveći broj stanovnika u Republici Hrvatskoj imaju: Zagreb (790.017), Split (178.012), Rijeka (128.624), Osijek (108.048), Zadar (75.062), Velika Gorica (63.517), Slavonski Brod (59.141), Pula (57.460), Karlovac (55.705), Sisak (47.768) i Varaždin (49.946). 
politizaciji regionalnog sustava Hrvatske, to jest u težnji da regionalizacija proizlazi iz razvojnog zahtjeva općine, a ne iz razvojnog koncepta Hrvatske kao cjeline."“41

Na tragu Šimunovićeva upozorenja da se regionalizacija ne bi smjela politizirati, Krešić ukazuje na to da „nijedna kroz povijest stvorena, bez obzira na njezin naziv, prostorna struktura ili regionalizacija nije imala gospodarsko značenje.“"42

Ekonomskim aspektima regionalizma bavili su se i brojni drugi autori. Kao ozbiljna nastojanja u pristupu ovoj temi izdvajaju se mišljenja stručnjaka s Ekonomskog instituta u Zagrebu: Lovrinčevića, Marića i Rajha, koji su se bavili problematikom regionalizacije na način da su ponudili veći broj simulacija i različitih koncepcija o optimalnoj organizaciji prostora Republike Hrvatske, s posebnim osvrtom na različite modele i učinke podjele Republike Hrvatske na statističke regije. Oni su u postupku pristupanja Hrvatske u EU zagovarali tezu da ,potencijalna statistička regionalizacija Hrvatske na dvije regije NUTS II (varijanta 8) osigurava zadovoljavanje kriterija broja stanovnika i maksimalan iznos potencijalnih sredstava iz EU-fondova. No nedostaci su te varijante izrazito nedovoljna razina interregionalne heterogenosti i intraregionalne homogenosti. Dalje, zbog heterogenosti ukupnog hrvatskog prostora ova varijanta nudi dvije velike regije i značajno otežava formuliranje i praćenje učinaka regionalne politike. Ona bi vjerojatno državnoj administraciji bila prihvatljiva zbog očekivanog financijskog učinka, ali stručna analiza ukazuje na nekvalitetnu osnovicu koju bi ta varijanta predstavljala za dugoročno vođenje regionalne politike. ${ }^{\text {“43 }}$

\section{STAJALIŠTA POLITOLOGA}

Od hrvatskih politologa, na ovom mjestu kao referentnog znalca ove problematike potrebno je izdvojiti profesora Milardovića. On u politološkoj dokumentarističkoj studiji slučaja o Istarskom demokratskom saboru, utvrđuje da „regionalizam nastaje kao odgovor na državni centralizam“ ${ }^{44}$ ističe da „načelo supsidijarnosti, inače utkano u doktrinu kršćanske demokracije, kazuje da društvo nižega reda, ukoliko je u stanju obaviti poslove i zadaće, te poslove i zadaće ne smije prepustiti društvu višega reda“"45 te zaključuje da se kao regionalizam može označiti djelovanje u kojem ,sljedbenici pokreta zahtijevaju veći stupanj autonomije u odnosu na

41 Šimunović, I., „Regionalni koncept razvitka Hrvatske“, Društvena istraživanja, god. 1, 1992., broj 1, str. 48-49.

42 Krešić, I., „Regionalna ili policentrična dugoročna orijentacija gospodarskog razvitka Istre“, Ekonomski pregled, god. 46, 1995., broj 3-4, str. 312.

43 Lovrinčević, Ž., Marić, Z., Rajh, E., „Kako optimalno regionalizirati Hrvatsku“, Ekonomski pregled, god. 56, 2005., broj 12, str. 1155.

44 Milardović, A., Regionalizam, autonomaštvo, federalizam ili separatizam, Pan liber, Osijek, 1995., str. 12.

45 Milardović, A., op. cit., str. 19. 
središnju vlast, unutar okvira države, ne ugrožavajući državni okvir, suverenitet i teritorijalnu cjelovitost.“"46

U odnosu na temu rada svakako treba spomenuti profesora Maldinija. On naglašava da je bit regionalizma u preraspodjeli državne moći iz centra na razinu regija što doprinosi demokratizaciji političkog života, a autor odbacuje strah da regionalizam kao pokret vodi u razbijanje države odnosno njezina suvereniteta, pa tako navodi da „od nekadašnjeg oponiranja centrifugalnoj dinamici političke unitarizacije s naglašenim obilježjima tradicionalizma i konzervatizma, regionalizam se sve više iskazuje kao liberalistički zahtjev za većim stupnjem demokratičnosti, za ostvarenjem građanskih prava (manjinskih, etničkih) i za primicanjem procesa političkog odlučivanjaštobliže građanimai mjestu njihova svakodnevnog življenja“, ${ }^{47}$ a upravo u Hrvatskoj je „regionalizam prošao put od prvotnog anatemiziranja i proskribiranja kao anacionalnog autonomaštva (u razdoblju stvaranja i uspostave nacionalne države i naglašavanja nacionalnog jedinstva), preko njegova prihvaćanja kao legitimne političke opcije (u razdoblju obnovljene demokratizacije početkom drugog desetljeća tranzicije), do promoviranja regionalizma kao bitne sastavnice javnih politika u okviru koncepta Europe regija (u razdoblju procesa pristupanja Hrvatske Europskoj uniji i danas, kad je Hrvatska njezina punopravna članica).“48

Politologinja Mendeš, govoreći o pojmu „dobrog upravljanja“, ukazuje na značaj participacije građana u političkom procesu i razbija strah od decentralizacije te ističe da ,intenzivna participacija građana u političkom procesu - podrazumijeva sudjelovanje svih onih kojih se određeni problem tiče“ ${ }^{49}$ dok „,veća decentralizacija ne bi smjela dovesti u pitanje konzistentnost i poštivanje zajedničkih ciljeva." ${ }^{\circ 0}$ Ona pojam tzv. višerazinskog upravljanja povezuje s principom supsidijarnosti koji znači ,da će neku djelatnost obavljati ona upravljačka razina (lokalna, regionalna, nacionalna, europska) koja je može najbolje obaviti. Time se ide u prilog nižim razinama javne uprave, onim razinama koje su bliže građanima. To je jedan od uzroka snažnog procesa decentralizacije, ali i procesa devolucije djelatnosti koje su nekad bile u nadležnosti države na tijela koja se nalaze ispod te razine. ${ }^{\text {"51 }}$

Od aktivnih hrvatskih političkih osoba, Šeks spada u one koji su se, između ostalog, bavili pitanjem optimalne teritorijalne organizacije, pri čemu je, uviđajući da ne postoje apsolutno prihvatljiva ili zadana rješenja, istaknuo da je pri određivanju optimalne teritorijalne organizacije nužno primjenjivati više kriterija, koji u sebi sadrže više elemenata, pa je tako naveo sljedeće kriterije: 1) demografski kriteriji, 2) geografski kriteriji, 3) gospodarsko/razvojni kriteriji, 4) financijski kriteriji, 5)

46 Milardović, A., op. cit., str. 52.

47 Maldini, P., „Politički i administrativni aspekti regije: regionalizam, regionalizacija i regionalne prilike“, Zbornik Sveučilišta u Dubrovniku, god. 1, 2014., broj 1, str. 127.

48 Maldini, P., op. cit., str. 128.

49 Mendeš, I., „Načela javne uprave i upravljanja u Europskoj uniji“, Anali Hrvatskog politološkog društva, god. 1, 2004., broj 1, str. 249.

50 Mendeš, I, op. cit., str. 249-250

51 Mendeš, I., op. cit., str. 250. 
administrativni kriteriji. ${ }^{52}$ U kontekstu razgovora o regionalizaciji Hrvatske, Šeks je ustvrdio (2010. godine) da jedna od reformi je i ,regionalizacija Hrvatske koja mora biti kvalitetno provedena jer će to kasnije utjecati na razvoj države u cjelini. “53

\section{STAJALIŠTE GEOGRAFA}

Ponešto disonantno mišljenje, ali s geografskog stajališta, zastupa geograf Magaš koji polazi od stava da je ,upravno-teritorijalni ustroj prvorazredno političko pitanje, ali pri tome treba nadilaziti povijesne percepcije i demografske opservacije koje ne uvažavaju najnovije znanstvene spoznaje različitih disciplina (upravnog prava, ekonomije, geografije i dr.), te nove prostorne procese (demografski razvoj, izgradnju prometne infrastrukture, prometno-vremensku konvergenciju prostora $\mathrm{i}$ sl.). ${ }^{" 54}$ Prenaglašavajući gravitacijsko značenje pojedinih gradova (on ih nabraja sedam: Zagreb, Split, Rijeka, Osijek, Zadar i Slavonski Brod) i kriterija za određivanje statističkih regija za teritorijalnu organizaciju države, Magaš ističe da su dva osnovna ,polazišta za mogući novi upravno-teritorijalni preustroj zemlje: 1) odgovarajuće vrednovanje postojećih sjedišta i njihova suvremena utjecaja, 2) primjena parametara regionalizacije Europske unije (NUTS-3). “55 Zastupajući zastarjelo shvaćanje regionalizma kao procesa koji vodi autonomaštvu i separatizmu i protiveći se podjeli Republike Hrvatske na pet (povijesnih) regija, Magaš smatra da bi za hrvatsku samostalnost bilo pogubno „,ako je, kao što impliciraju pojedine radikalnije izjave i izvori, koncept s pet regija zasnovan na autonomaškom ili čak separatističkim zamislima podjela na zemlje Slavoniju i Dalmaciju te tri regije banske (sjeverozapadne) Hrvatske. To bi značilo da preživjeli koncept osmanskih, mletačkih i habsburških imperijalističkih prekrajanja Hrvatske ima snažnija uporišta od autohtonog i danas zaživjelog županijskog sustava te modernih gravitacijskoživotnih prožimanja. (...) Dakle, predloženi model s pet regija jest preradikalan, loš i neodgovarajući jer se miješaju razine NUTS-regionalizacije i periferiziraju veliki dijelovi Hrvatske. Najmanje tri središta (od barem sedam) u Jadranskoj Hrvatskoj trebali bi biti Rijeka, Zadar i Split. Moguć je i fleksibilniji pristup ovoj problematici prepoznavanjem prvoga reda - u prostoru Jadranske Hrvatske Pule, a u kontinentalnoj Hrvatskoj konurbacije Vukovar - Vinkovci. Tako bi se broj potencijalnih regija u Hrvatskoj definirao na maksimalno devet odnosno 10 sa Zagrebom, koje bi brojem stanovnika i gravitacijskom snagom svojih sjedišta odgovarale razini NUTS-3 regija u drugim članicama EU-a. Time bi se izbjegle mogućnosti autonomašenja, separatizma i politizacije vernakularnih prostornih

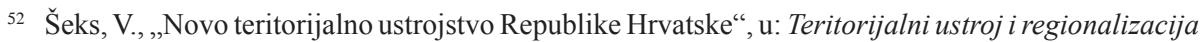
Republike Hrvatske u kontekstu Europskih integracija: zbornik radova, ur. Cvitan, O., Split, 2010., str. 20-21.

53 Šeks, V., op. cit., str. 23.

54 Magaš, D., ,Jadranska Hrvatska iz perspektive regionalizacije Europske unije“, Političke analize, god. 5, 2014., broj 17, str. 24.

55 Magaš, D., op. cit., str. 24. 
kompleksa te omogućio demografski, gospodarski i prometno-geografski optimalni preustroj u svrhu poticanja općega razvoja zemlje."“56

\section{STAJALIŠTA SOCIOLOGA}

Iako danas djeluje anakrono, za prilike s početka 90-ih godina 20. stoljeća, kada je Republika Hrvatska bila izložena agresiji i centralizacija države je bila u funkciji očuvanja njezina suvereniteta i integriteta, razumljivo je promišljanje urbanog sociologa Rogića da se ,primjerena regionalna teritorijalizacija hrvatskog društva ne može izgraditi ako je njezina pretpostavka osporena hrvatska država. “57 On drži da funkcija županije nije ista ili slična funkciji regije, odnosno da je funkcija regije „ekologijska i kulturna rekonstrukcija zavičajnog teritorija“ ${ }^{58}$ dok je županija element državne organizacije, a njezin cilj je „,izgradnja primjerene upravne teritorijalne sheme kako bi država mogla funkcionirati stvarajući jedinstveni pravni poredak na cijelom teritoriju kojim raspolaže. Cilj je županije, dakle, upravna homogenizacija zemlje. Cilj je regije, naprotiv, ekologijska i kulturna diferencijacija te iste zemlje. ${ }^{659}$

Sociolog Vukelić, iznoseći pozitivne aspekte regija i regionalizma, a odbacujući separatizam kao polazište ili posljedicu regionalizma, ističe da „nekadašnji separatizam u europskim zemljama zamijenjen je novom strategijom zaobilaženjem svojih nacionalnih vlada i izravnim obraćanjem Bruxellesu pomoću dviju institucija: Odbora regija, u kojoj participiraju samo države članice Europske unije i preko Skupštine europskih regija, u kojoj mogu participirati regije iz svih europskih zemalja, a ne samo iz zemalja članica Europske unije." ${ }^{60}$

\section{ZAKLJUČAK}

Suvremeni regionalni pristup osamostaljuje regiju kao razvojni entitet, te po načelu supsidijarnosti regija preuzima na sebe sve ono što može neovisno obaviti.

56 Magaš, D., str. 28-29.

57 Rogić, I., „Hrvatska i njezine regije“, Društvena istraživanja, Zagreb, god. 1., 1992., broj 1, str. 31; O iredentizmu i autonomaštvu kao smetnjama hrvatskom regionalizmu, vidi u: Strčić, P., „Nacija i nacionalizam: hrvatstvo, mađarstvo, talijanstvo, srpstvo, slovenstvo, crnogorstvo i bošnjaštvo na hrvatskoj obali Jadrana u XIX. i XX. stoljeću“, Kolo, god 10, 2000., broj 2, str. 75; Žuljić, S., Hrvatska Istra: suvremene narodnosne prilike, Zagreb, Nakladni zavod Globus, 1994., str. 36; Vrandečić, J., „Dalmatinski autonomistički pokret u XIX. Stoljeću“, Zagreb, Dom i svijet, 2002., str. 11; Katušić, I., Vječno progonstvo Nikole Tommasea, Zagreb, Liber, 1975., str. 79-80.

58 Rogić, I., op. cit., str. 32.

59 Rogić, I., op. cit., str. 32.

60 Vukelić, K., „Regionalizacija danas, centralizacija sutra“, Revija za sociologiju, god. 36, 2005., broj 1-2, str. 81; O značaju Odbora regija u sustavnom razvijanju europskih regija detaljnije vidi u: Rubić, M., „Uloga Odbora regija u kohezijskoj politici Europske unije“, Zbornik radova Pravnog fakulteta $u$ Splitu, god. 52, 2015., broj 4, str. 955-986. 
Na taj se način država ne isključuje, već se njezina uloga mijenja i stavlja u odnos u kojem je ona efikasna i korisna za cijelo područje države.

Prednosti regionalizacije su: veći ekonomsko-financijski kapacitet regionalnih jedinica i time veća mogućnost poticanja razvoja, bolja organizacija javnih službi na regionalnoj razini, kvalitetnije zadovoljavanje potreba na lokalnoj razini i jačanje interesa lokalnog stanovništva za sudjelovanje u političkom životu. ${ }^{61}$

Regionalizam u Republici Hrvatskoj nije opasnost za opstojnost središnje države, ${ }^{62}$ već se kao glavna kočnica formiranju i jačanju samoupravnih regija može pojaviti nespremnost političkih elita da omoguće raspodjelu političke moći i time smanje ulogu i utjecaj središnje vlade, ali i vrhuški političkih stranaka koje iz središnjice upravljaju političkim procesima na cijelom području države.

Sadašnji je teritorijalni ustroj područne (regionalne) samouprave, koji sačinjava 20 županija i Grad Zagreb, neracionalan i nužno je smanjiti broj teritorijalnih jedinica, pri čemu je najbolje poći od prirodnih i povijesnih regija s kojima postoji snažna identifikacija stanovništva. ${ }^{63}$ Spajanje županija, uz moguće preinake

${ }^{61}$ Dokument Europske unije, Europska vladavina: Bijela knjiga iz 2001. g., naglašava značenje pet ključnih načela kvalitetne vladavine u suvremenim europskim prilikama, a to su otvorenost, sudjelovanje, odgovornost, učinkovitost i usklađenost. Politika Europske unije ide za tim da snažno naglasi činjenicu da se regionalno i lokalno znanje i uvjeti uzimaju u obzir kada se stvaraju prijedlozi političkih mjera, što znači da se respektira činjenica da rješenja u tom području moraju biti zasnovana na načelu demokratskog ustrojavanja regija koje će poštovati njihove različite kulturološke, povijesne, ekonomske, zemljopisne i ine okolnosti. - „Europska vladavina: Bijela knjiga“, Revija za socijalnu politiku, god. 12, 2005., br. 2, str. 189-213.

62 Prekogranična suradnja županija ne doživljava se kao opasnost za suverenost i integritet države, pa je u tom smislu ratificirana Okvirna europska konvencija o prekograničnoj suradnji između teritorijalnih zajednica ili vlasti (NN - MU 10/03).

Transnacionalni regionalizam teži progresu bez obzira na državne granice i korijen je sintagme o „Europi regija“. Izraziti primjer transnacionalne regije jest Alpe-Adria, koja obuhvaća geografsko područje Alpa i Sjevernog i Srednjeg Jadrana, s regijama iz Austrije, Italije, Mađarske, Slovenije i Hrvatske. - http://www.mvep.hr/hr/vanjska-politika/multilateralni-odnosi-staro-ijvhj/radna-zajednicaalpe-jadran--opcenito/

63 Prema popisu stanovništva iz 2011. godine,

https://www.dzs.hr/hrv/censuses/census2011/results/htm/H01_01_05/H01_01_05.html (uvid 18. XII. 2018.), čak 25.491 osoba izjasnila se kao Istranin, dok je udio stanovnika koji sū kao narodnost naveli neku drugu regionalnu pripadnost znatno manji od 1000. U sadašnjem (9.) sazivu Hrvatskog sabora regionalističke stranke ukupno imaju 4 zastupnika: 3 su iz reda Istarskog demokratskog sabora (IDS) i 1 iz reda Hrvatskog demokratskog saveza Slavonije i Baranje (HDSSB), http://www.sabor.hr/zastupnici-9 (uvid 18. XII. 2018.).

Odluka o granicama županija u konačnici je političke prirode jer je donosi Hrvatski sabor koji interpretira zakonske kriterije za njihovo odlučivanje. Možda je najbolje kod kreiranja rješenja područne (regionalne) samouprave krenuti iz početka, bez obveza (robovanja) prema burnoj državnopravnoj prošlosti Hrvatske, koja je uključivala različite državne saveze i različita uređenja vlasti na lokalnoj razini (posebno po pitanju veličine jedinica i njihovih ovlasti) i njezina odnosa prema središnjoj državnoj vlasti. Dakle, po ovom pitanju ne treba robovati povijesnim rješenjima, pa tako ni povijesnim regijama, koje se često i preklapaju, ni županijama glede područja koje su obuhvaćale ili sada obuhvaćaju. Jednostavno, može se slijediti logika situacije odnosno logika cilja koji se želi i može postići određenom teritorijalnom organizacijom odnosno pravo na egzistenciju imaju one jedinice koje mogu odgovoriti na povijesne, tradicijske, kulturološke i gospodarstveno-financijske izazove. Percepcija odnosno mišljenje građana o granicama političkih teritorijalnih jedinica, u ovom slučaju samoupravnih regija, bitni su jer je upitno koliko su se građani identificirali s postojećim županijama, ali i koliko se poistovjećuju s povijesnim regijama. 
postojećih županijskih granica, dovelo bi do smanjenja njihova broja, ali i do povećanja stanovništva novih teritorijalnih jedinica i do jačanja njihove ekonomske snage. Nove samoupravne regije - radno ih se može nazvati: Središnja Hrvatska, Dalmacija, Slavonija, Hrvatsko primorje i Istra i Grad Zagreb - imale bi u prosjeku oko 800.000 stanovnika. ${ }^{64}$ Sjedišta novih regija bili bi najveća urbana središta odnosno jedini hrvatski gradovi koji imaju više od 100.000 stanovnika (Zagreb, Osijek, Rijeka, Split), dok bi središte Središnje Hrvatske mogao biti njezin najveći grad Varaždin. Sjedište predstavničkog tijela novih regija nužno ne bi trebalo biti u njezinu središtu. Dodatno bi se, zbog specifičnosti određenih područja koja su snažno razvila svoj regionalni identitet i imaju jaku ekonomsku bazu, poput Istre, moglo razmisliti i o stvaranju dodatnih regija, no to bi dovelo do značajne neujednačenosti teritorijalnih jedinica po površini i broju stanovnika ${ }^{65}$

Smanjenje broja županija bitno je jer se na postojeću teritorijalnu podjelu nadovezuju i podjele odnosno organizacije upravnih tijela (policija, uredi državne uprave, socijalne službe, mirovinski zavodi i dr.). U prilog potvrdi da je moguće i potrebno racionalizirati postojeći županijski ustroj, govori činjenica da su neka državna tijela na područnoj (regionalnoj) razini ustrojila svoje službe u manji broj jedinica: Carinska uprava podijeljena je na 4 područna ureda u Zagrebu, Rijeci, Osijeku i Splitu, ${ }^{66}$ Trgovački sudovi ustrojeni su u 8 gradova: Bjelovaru, Osijeku, Pazinu, Rijeci, Splitu, Varaždinu, Zadru i Zagrebu, ${ }^{67}$ Županijski sudovi ustrojeni su u 15 gradova, ${ }^{68}$ Županijska državna odvjetništva ustrojena su u 15 gradova, ${ }^{69}$ Policijski ured za suzbijanje korupcije i organiziranog kriminaliteta ima Odjele u Zagrebu, Splitu, Rijeci i Osijeku..$^{70}$

Nakon određivanja područja (teritorija) jedinica područne (regionalne) samouprave, od odlučne je važnosti za postizanje svrhe njihova postojanja odrediti

64 Prema Popisu stanovništva iz 2011. godine,

https://www.dzs.hr/hrv/censuses/census2011/results/xls/Preg_01_HR.xls (uvid 13. XII. 2018.), regija Središnja Hrvatska, u koju bi se mogle spojiti županije Krapin̄sko-zagorska, Sisačko-moslavačka, Karlovačka, Varaždinska, Koprivničko-križevačka, Bjelovarsko-bilogorska, Virovitičko-podravska i Međimurska, imala bi oko 900.000 stanovnika; regija Dalmacija, u koju bi ušle županije Dubrovačkoneretvanska, Splitsko-dalmatinska, Šibensko-kninska i Zadarska, imala bi oko 950.000 stanovnika; regija Slavonija, u kojoj bi se spojile županije Požeško-slavonska, Brodsko-posavska, imala bi oko 850.000 stanovnika; regija Hrvatsko primorje i Istra, koju bi sačinjavale sadašnje županije Istarska, Primorskogoranska, Karlovačka i Ličko-senjska, imala bi oko 700.000 stanovnika, dok bi regija koju bi sačinjavali Zagreb i gradovi koji s njim čine funkcionalnu cjelinu i čiji stanovnici dnevno odlaze u Zagreb radi posla ili zadovoljenja drugih potreba (zdravstvenih, obrazovnih i sl.) imala oko 1.100.000 stanovnika.

65 Regija Istra imala bi samo oko 210.000 stanovnika. 2018.).

66 https://carina.gov.hr/o-upravi/djelokrug/ustrojstvo/podrucni-carinski-uredi/2790 (uvid 18. XII.

67 https://pravosudje.gov.hr/pristup-informacijama-6341/ostale-informacije/pravosudna-tijela-rh/ trgovacki-sudovi-6437/6437 (uvid 18. XII. 2018.).

68 https://pravosudje.gov.hr/pristup-informacijama-6341/ostale-informacije/pravosudna-tijela-rh/ zupanijski-sudovi-6439/6439 (uvid 18. XII. 2018.).

69 http://www.dorh.hr/Default.aspx?sec=628 (uvid 18. XII. 2018.).

70 http://stari.mup.hr/159.aspx (uvid 18. XII. 2018.). 
odnosno proširiti njihove ovlasti i osigurati odgovarajuća financijska sredstva za njihov rad.

Glede ovlasti, treba istaći da Ustav Republike Hrvatske i pripadajući zakoni omogućuju da se jedinicama područne (regionalne) samouprave dodijele brojni i različiti poslovi. ${ }^{71} \mathrm{U}$ kontekstu širenja ovlasti jedinica područne (regionalne) samouprave, čini se pozitivnom ideja (odluka) ministra uprave Republike Hrvatske Lovre Kuščevića, iznesena dana 12. prosinca 2018., na 5. sastanku Vlade Republike Hrvatske sa županima, predstavnicima Udruge gradova, Udruge općina te predsjednikom Odbora za lokalnu i područnu (regionalnu) samoupravu u Hrvatskom saboru. On je, u okviru reforme sustava javne uprave, predstavio „reformsku mjeru: Povjeravanje poslova Ureda državne uprave županijama, istaknuvši: Predviđeno povjeravanje poslova Ureda državne uprave županijama predstavlja značajnu funkcionalnu i fiskalnu decentralizaciju, a ova reforma će rezultirati jačanjem decentralizacije uz primjenu načela supsidijarnosti. " 72 Središnja bi država, kroz upravni nadzor nad prenesenim poslovima, obavljala kontrolu poslova državne uprave. Ovom mjerom ne dovodi se u pitanje zakonitost rada uprave niti se županima omogućava nezakoniti nadzor i utjecaj na rad upravnih tijela. Naime, glavne pravne vrednote na kojima bi trebala biti utemeljena javna uprava, pa tako i područna (regionalna) samouprava kao njezin dio, trebale bi biti zakonitost u svim njezinim aspektima (organizacijski, materijalni, proceduralni) i pravna odgovornost uprave. Sama činjenica da je na čelu upravnog aparata u područnoj (regionalnoj) samoupravi župan, kojega na izborima neposredno biraju građani, ${ }^{73}$ a ne predstojnik ureda državne uprave kojega (prema sadašnjoj regulativi) bira Vlada Republike Hrvatske ${ }^{74}$ ne upućuje na politizaciju uprave odnosno činjenica da je do sada čelnika uprave birala središnja (politička) vlast nije garantirala ni na jedan način veći stupanj zakonitosti u radu uprave, a niti se može otkloniti prigovor da je politička procjena bila važan razlog kod odabira takvog čelnika uprave. Jednostavno rečeno, službenici u jedinicama regionalne (područne) samouprave u radu se moraju držati Ustava Republike Hrvatske, zakona i podzakonskih akata, a za one koji ne poštuju procesne i materijalne odredbe zakona predviđene su disciplinske mjere, uključujući i mjeru prestanka službe. ${ }^{75}$

71 Deklaracija o regionalizmu u Europi (Skupština europskih regija, 1996.) u čl. 3. ističe da bi provedba nacionalnog zakonodavstva, u pravilu, trebala biti u samoupravnom ili prenesenom djelokrugu regije, da bi regije trebale imati ovlasti u pogledu svih poslova s dominantno regionalnom dimenzijom te da je potrebno osigurati izbjegavanje tzv. dvostrukog upravnog kolosijeka odnosno da na istom području postoje upravne strukture središnje države i samoupravnih jedinica, a navode se i poslovi koji su u brojnim zemljama preneseni u samoupravni djelokrug regija: regionalna ekonomska politika, regionalno prostorno planiranje, graditeljstvo i stambena politika, telekomunikacijska i prometna infrastruktura, energija i okoliš, poljoprivreda i ribarstvo, obrazovanje na svim razinama, sveučilišta i istraživanje, kultura i mediji, javno zdravstvo, turizam, razonoda i sport, policija i javni red.

${ }^{72}$ https://uprava.gov.hr/print.aspx?id=14839\&url=print (uvid 19. XII. 2018.).

73 Zakon o lokalnim izborima, NN 144/12, 121/16.

74 Čl. 56. Zakona o sustavu državne uprave, NN 150/11, 12/13, 93/16, 104/16.

75 Čl. 65. Zakona o službenicima i namještenicima u lokalnoj i područnoj (regionalnoj) samoupravi, NN 86/08, 61/11, 04/18. Detaljnije o odgovornosti zaposlenih u jedinicama područne (regionalne) samouprave u vezi s njihovim radom, vidi u: Lozina, D., Juras, D., „Odgovornost za povredu službene 
Za učinkovito funkcioniranje područne (regionalne) samouprave vrlo su važna financijska sredstva kojima ona raspolaže, a nesukladnost raspoloživih sredstava i povjerenih ovlasti dovodi u pitanje ostvarenje njihove uloge, prvenstveno uloge pokretača sveukupnog razvoja. Po ovom pitanju važno je da županije imaju što veći dio izvornih prihoda te da u što manjoj mjeri ovise o dotacijama središnje državne vlasti jer činjenjem sustava područne (regionalne) samouprave ovisnim o financijskoj pomoći iz središnjeg proračuna, onemogućava se njegova potrebna samostalnost i aktivna uloga u razvoju svog područja. ${ }^{76}$ Imovinu u državnom vlasništvu treba prepustiti na raspolaganje lokalnim jedinicama. Osim osiguranja financijskih sredstava, bitno je regijama omogućiti da imaju i određenu autonomiju u odlučivanju o korištenju tih sredstava. Nove je regije potrebno ojačati radi apliciranja odnosno korištenja fondova Europske unije za regionalni razvoj, pri čemu je bitno da broj statističkih regija odnosno statistički izraženi razvoj pojedinih regija ne bude zapreka za pristup financijski najizdašnijem cilju europske kohezijske politike (cilj Konvergencija). ${ }^{77}$ Značaj statističkih regija prepoznala je i Vlada Republike Hrvatske, čiji se predsjednik Andrej Plenković dana 15. siječnja 2019. godine u Banskim dvorima sastao s predstavnicima Hrvatske zajednice županija, Udruge gradova i općina te s predsjednicima nadležnih odbora Hrvatskoga sabora i predstavio im prijedlog nove statističke klasifikacije prostornih jedinica u Republici Hrvatskoj (NUTS 2), pri čemu je istaknuo da je Vlada ,angažirala Institut za razvoj međunarodnih odnosa da napravi stručnu podlogu kako bismo u novim okolnostima i na temelju stečenog iskustva iz proteklih pet, šest godina zajednički promislili i donijeli odluku koja će trasirati novu regionalnu kartu potpora i povezati podjelu prostornih jedinica s najvećim dijelom buduće financijske perspektive između 2021. i 2027. godine. ${ }^{\text {778 }}$

odnosno radne dužnosti službenika i namještenika u lokalnoj i područnoj samoupravi u Republici Hrvatskoj“, Zbornik radova Pravnog fakulteta u Splitu, god. 52, broj 2, 2015., str. 335-368.

Iako treba voditi računa o tome da proračun područne samouprave bude opterećen izdacima za zaposlene u onoj mjeri koliko je nužno da službenik radi na određenim poslovima, najskuplja i najneučinkovitija uprava jest ona koja ne radi zakonito i pravovremeno i k tome ne odgovara za svoje greške prema poslodavcu i prema korisnicima usluga.

76 Izvori sredstava i financiranje poslova iz samoupravnog djelokruga jedinica lokalne i područne (regionalne) samouprave, raspodjela prihoda od poreza na dohodak, fiskalno izravnanje jedinica lokalne i područne (regionalne) samouprave te financiranje decentraliziranih funkcija, propisani su Zakonom o financiranju jedinica lokalne i područne (regionalne) samouprave, NN 127/17.

77 BDP po stanovniku znatno se razlikuje za pojedine županije, pa je BDP po stanovniku za cijelu Hrvatsku u 2015. godini bio 10.586 eura, najviši je bio u Gradu Zagrebu 18.579 eura, a najmanji u Virovitičko-podravskoj županiji 5852 eura. Postojeće statističke regije imaju približan BDP po stanovniku: Kontinentalna Hrvatska 10.972 eura, a Jadranska Hrvatska 10.172 eura. - https://www.dzs.hr/Hrv_Eng/ publication/2018/12-01-03_01_2018.htm (uvid 24. XII. 2018.). Na temelju Nacionalne klasifikacije prostornih jedinica za statistiku 2012., NN 96/2012, Republika Hrvatska podijeljena je na dvije statističke regije: Jadransku Hrvatsku (obuhvaća sedam županija koje imaju morsku granicu, a prema podacima iz Popisa stanovništva iz 2011. u toj regiji živi 1.468.921 stanovnik) i Kontinentalnu Hrvatsku (obuhvaća ostalih trinaest županija i Grad Zagreb i u njoj živi 2.960.157 stanovnika). Ovakva statistička podjela omogućava korištenje sredstava iz fondova Europske unije po najpovoljnijim uvjetima odnosno uz najniže stope sufinanciranja iz izvora izvan Europske unije).

$78 \mathrm{https} / /$ vlada.gov.hr/vijesti/plenkovic-zupanima-o-novom-prijedlogu-prostornih-jedinica-vladi-jevazno-vase-misljenje-i-otvorena-je-za-prijedloge/25123 (uvid 22. I. 2019.). 


\section{LITERATURA}

Babac, B., „Oblikovanje hrvatskoga regionalnog političko-upravnog ustrojstva u razmeđu suvremenosti, nacionalne tradicije i europeizacije - prethodni iskazi“, Teritorijalni ustroj i regionalizacija Republike Hrvatske u kontekstu Europskih integracija: zbornik radova, ur. O. Cvitan, Split, 2010.

Blažević, R., „Hrvatske regije i županije u povijesnom ključu“, Nova hrvatska lokalna $i$ regionalna samouprava (ur. J. Barbić), Zagreb, HAZU, 2010., str. 175-198.

Cvitan, O., Uvodnik znanstveno-stručnog skupa: Teritorijalni ustroj i regionalizacija Republike Hrvatske u kontekstu Europskih integracija, Teritorijalni ustroj i regionalizacija Republike Hrvatske u kontekstu Europskih integracija: zbornik radova, ur. O. Cvitan, Split, 2010.

Deklaracija o regionalizmu u Europi, Skupština europskih regija, 1996.

Đulabić, V., „Položaj županija u statističkoj i političkoj regionalizaciji Hrvatske“, Dvadeset godina lokalne samouprave u Hrvatskoj (ur. I. Koprić), Institut za javnu upravu, Zagreb, 2013., str. 183-200.

„Europska vladavina: Bijela knjiga“, Revija za socijalnu politiku, god. 12, 2005., br. 2 , str. 189-213.

file://C:/Users/djuras/Documents/Državni\%20zavod\%20za\%20statistiku\%20 Republike\%20Hrvatske.pdf

Grubišin, M., „O mjerilima i kriterijima teritorijalnog ustroja Republike Hrvatske u odnosu na države njenog okruženja“, Teritorijalni ustroj i regionalizacija Republike Hrvatske u kontekstu Europskih integracija: zbornik radova, ur. O. Cvitan, Split, 2010.

https://carina.gov.hr/o-upravi/djelokrug/ustrojstvo/podrucni-carinski-uredi/2790 (uvid 18. XII. 2018.).

https://pravosudje.gov.hr/pristup-informacijama-6341/ostale-informacije/pravosudnatijela-rh/trgovacki-sudovi-6437/6437

https://pravosudje.gov.hr/pristup-informacijama-6341/ostale-informacije/pravosudnatijela-rh/zupanijski-sudovi-6439/6439https://www.dzs.hr/hrv/censuses/census2011/results/ htm/H01_01_05/H01_01_05.html

http://stari.mup.hr/159.aspx

https://uprava.gov.hr/print.aspx?id=14839\&url=print

https://vlada.gov.hr/vijesti/plenkovic-zupanima-o-novom-prijedlogu-prostornihjedinica-vladi-je-vazno-vase-misljenje-i-otvorena-je-za-prijedloge/25123

https://www.dzs.hr/hrv/censuses/census2011/results/xls/Preg_01_HR.xls

https://www.dzs.hr/Hrv_Eng/publication/2018/12-01-03_01_2018.htm

http://www.dorh.hr/Default.aspx?sec=628

http://www.mvep.hr/hr/vanjska-politika/multilateralni-odnosi-staro-ijvhj/radnazajednica-alpe-jadran--opcenito/

http://www.sabor.hr/zastupnici-9 
Ivanišević, S., „Teritorijalna osnova lokalne i regionalne samouprave uz posebni osvrt na položaj grada Zagreba i njegovu samoupravu“, Hrvatska javna uprava, god. 2, 2000., broj 4, str. 585-602.

Katušić, I., Vječno progonstvo Nikole Tommasea, Zagreb, Liber, 1975.

Klarić, M., „Moguće perspektive razvoja lokalne i regionalne samouprave u Republici Hrvatskoj“, u: Teritorijalni ustroj i regionalizacija Republike Hrvatske u kontekstu Europskih integracija: zbornik radova, ur. O. Cvitan, Split, 2010.

Koprić, I., „Je li moguća regionalizacija Hrvatske? Institucionalna i politička ograničenja“, Političke analize, god. 5, 2014., broj 17, str. 9-16.

Koprić, I., „Teritorijalna organizacija Hrvatske: stanje, kriteriji za prosudbu racionalnosti i prijedlog novog sustava“, Nova hrvatska lokalna i regionalna samouprava (ur. J. Barbić), Zagreb, HAZU, 2010., str. 109-144.

Koprić, I., „Uloga županija u hrvatskom sustavu lokalne samouprave i uprave 1990ih i perspektive regionalizacije nakon promjena Ustava iz 2000. godine“, Hrvatska javna uprava, Zagreb, god. 3, 2001., broj 1., str. 63-87.

Krešić, I., „Regionalna ili policentrična dugoročna orijentacija gospodarskog razvitka Istre“, Ekonomski pregled, god. 46, 1995., broj 3-4, str. 302-317.

Lalić-Novak, G., „Komparativna metoda u proučavanju javne uprave: potencijali i problemi“", Hrvatska i komparativna javna uprava, god. 15, 2015., broj 1, str. 9-32.

Lovrinčević, Ž., Marić, Z., Rajh, E., „Kako optimalno regionalizirati Hrvatsku“, Ekonomski pregled, god. 56, 2005., broj 12, str. 1109-1160.

Lozina, D., Lokalna samouprava - poredbeno i hrvatsko iskustvo, Pravni fakultet u Splitu, Split, 2004.

Lozina, D., Juras, D., „Odgovornost za povredu službene odnosno radne dužnosti službenika i namještenika u lokalnoj i područnoj samoupravi u Republici Hrvatskoj“, Zbornik radova Pravnog fakulteta u Splitu, god. 52, broj 2, 2015., str. 335-368.

Magaš, D., „Jadranska Hrvatska iz perspektive regionalizacije Europske unije“, Političke analize, god. 5, 2014., broj 17, str. 23-29.

Maldini, P., „Politički i administrativni aspekti regije: regionalizam, regionalizacija i regionalne prilike“, Zbornik Sveučilišta u Dubrovniku, god. 1, 2014., broj 1, str. 125-153.

Mendeš, I., „Načela javne uprave i upravljanja u Europskoj uniji“, Anali Hrvatskog politološkog društva, god. 1, 2004., broj 1, str. 247-252.

Milardović, A., Regionalizam, autonomaštvo, federalizam ili separatizam, Pan liber, Osijek, 1995.

Nacionalna klasifikacija prostornih jedinica za statistiku 2012., NN 96/12.

Okvirna europska konvencija o prekograničnoj suradnji između teritorijalnih zajednica ili vlasti, NN - MU 10/03.

Rogić, I., „Hrvatska i njezine regije“, Društvena istraživanja, Zagreb, god. 1., 1992., broj 1, str. 25-35. 
Rubić, M., „Uloga Odbora regija u kohezijskoj politici Europske unije“, Zbornik radova Pravnog fakulteta u Splitu, god. 52, 2015, broj 4, str. 955-986.

Strčić, P., „Nacija i nacionalizam: hrvatstvo, mađarstvo, talijanstvo, srpstvo, slovenstvo, crnogorstvo i bošnjaštvo na hrvatskoj obali Jadrana u XIX. i XX. stoljeću“, Kolo, god 10, 2000., broj 2, str. 74-80.

Šeks, V., „Novo teritorijalno ustrojstvo Republike Hrvatske“, u: Teritorijalni ustroj $i$ regionalizacija Republike Hrvatske u kontekstu Europskih integracija: zbornik radova, ur. O. Cvitan, Split, 2010.

Šimunović, I., „Hrvatski i europski regionalizam“, Ekonomski pregled, god. 46, 1995., broj 3-4, str. 292-301.

Šimunović, I., Planiranje ili pravo na budućnost, Marjan tisak, Split, 2005.

Šimunović, I., „Regionalni koncept razvitka Hrvatske“, Društvena istraživanja, god. 1, 1992., broj 1, str. 37-54.

Švaljek, S., „Regionalni identitet Istre“, Ekonomski pregled, god. 46, 1995., broj 3-4, str. 253-262.

Uredba (EZ) 1059/2003 od 26. V. 2003. o uspostavi zajedničke klasifikacije teritorijalnih jedinica za statistiku.

Ustav Republike Hrvatske, NN 56/90, 135/97, 113/00, 28/01, 76/10, 5/14.

Vukelić, K., „Regionalizacija danas, centralizacija sutra“, Revija za sociologiju, god. 36, 2005., broj 1-2, str. 78-85.

Vrandečić, J., „Dalmatinski autonomistički pokret u XIX. Stoljeću“, Zagreb, Dom i svijet, 2002.

Zakon o financiranju jedinica lokalne i područne (regionalne) samouprave, NN 127/17.

Zakon o Gradu Zagrebu, NN 62/01, 125/08, 36/09, 119/14.

Zakon o lokalnim izborima, NN 144/12, 121/16.

Zakon o lokalnoj samoupravi i upravi, NN 90/92, 94/93, 117/93, 5/97, 17/99, 128/99, 51/00, 105/00.

Zakon o lokalnoj i područnoj (regionalnoj) samoupravi, NN 33/01, 60/01, 129/05, 109/07, 125/08, 36/09, 150/11, 144/12, 19/13, 137/15, 123/17.

Zakon o područjima županija, gradova i općina u Republici Hrvatskoj, NN 90/92, 2/93, 58/93, 90/93, 10/94, 29/94.

Zakon o područjima županija, gradova i općina u Republici Hrvatskoj, NN 86/06, 125/06, 16/07, 95/08, 46/10, 145/10, 37/13, 44/13, 45/13, 110/15.

Zakon o službenicima i namještenicima u lokalnoj i područnoj (regionalnoj) samoupravi, NN 86/08, 61/11, 04/18 Zakon o sustavu državne uprave, NN 150/11, 12/13, 93/16, 104/16.

Žuljić, S., Hrvatska Istra: suvremene narodnosne prilike, Zagreb, Nakladni zavod Globus, 1994. 


\section{THEORETICAL APPROACHES ON REGIONAL SELF- GOVERNMENT IN THE REPUBLIC OF CROATIA}

Croatia has chosen (as an independent state and from 2013 as a full member of the European Union) to fully affirm the institutions of local and regional self-government. Croatian administration science has made significant advances in terms of acceptance of basic, for now, European, profiling of these institutions, but it is also aware of its' particularities on that path. As one of the most significant dubieties, the one on the concept of regional self-government appears, i.e. on the organization of that area, especially which territory would be encompassed by the units of regional self-government in the Republic of Croatia, as well as the authorities which would these units possess. In order to critically and wholly analyse the crucial questions of regional self-government in the Republic of Croatia, this paper also analyses perspectives of scientists in other areas: economists, political scientists, geographers and sociologists.

Key words: county, regional self-administration, regionalism, regions, Republic of Croatia, territorial organization 